\title{
ALTERNATIF SISTEM EKONOMI ISLAM UNTUK INDONESIA YANG LEBIH SEJAHTERA
}

\author{
Dian Indah Cahyani ${ }^{1}$ dan Sumadi ${ }^{2}$ \\ STIE-AAS Surakarta \\ ${ }^{1}$ Email: Dian.Indah@yahoo.com \\ ${ }^{2}$ Email: sum_1924@yahoo.com
}

\begin{abstract}
Economic development in a country or bangasa is the main foundation in order to realize the welfare of society. The economy of a country strong then, the country will be stronger. To this end, the trend of capitalism that has spread throughout the world led to the shifting economic world order. Understand the rich get richer, the poor poorer, unwittingly been entrenched in every society the world. Free competition, monopoly, is a product of capitalism that has a lot of miserable people in the country of Indonesia is no exception. Pancasila Economic System is an economic system that is excavated and built from the values espoused in Indonesian society

Economics is the knowledge of the events and feelings associated with human efforts as individuals (private), group (family of nations, organizations) in meeting the needs are endless. The economic function is to develop capabilities in the event of economic, analyzing and assessing the economic problems, whether they are individual, society and the national character.
\end{abstract}

Keywords: alternative, the economic system of Islam, prosperous

\section{PENDAHULUAN}

Pembangunan ekonomi dalam suatu negara atau bangasa merupakan pondasi utama dalam rangka mewujudkan kesejahteraan masyarakat. Ekonomi sebuah negara kuat maka, negaranya akan kuat. Akhir ini, trend kapitalisme yang telah merebak keseluruh dunia menyebabkan bergesernya tatanan dunia perekonomian. Paham yang kaya semakin kaya, yang miskin semakin miskin, tanpa disadari telah membudaya disetiap lapisan masyarakat dunia. Persaingan bebas, monopoli, merupakan produk kapitalisme yang telah banyak menyengsarakan masyarakat tidak terkecuali di negara Indonesia. Sistem Ekonomi Pancasila merupakan sistem ekonomi yang digali dan dibangun dari nilai-nilai yang dianut dalam masyarakat Indonesia
Ekonomi adalah pengetahuan peristiwa dan perasaan yang berkaitan dengan upaya manusia secara perseorangan (pribadi), kelompok (keluarga suku bangsa, organisasi) dalam memenuhi kebutuhan tidak terbatas. Adapun fungsi ekonomi adalah untuk mengembangkan kemampuan dalam mengenai peristiwa ekonomi, menelaah dan menilai masalah ekonomi, baik yang bersifat perseorangan, masyarakat maupun yang bersifat nasional.

Dalam pemikiran ekonomi Taqiyuddin an-Nabhani kata "ekonomi" bukanlah makna bahasa yang berarti hemat dan juga bukan berarti kekayaan, akan tetapi yang dimaksud adalah semata-mata istilah untuk suatu sebutan tertentu, yaitu kegiatan mengatur urusan harta kekayaan baik yang menyangkut kegiatan memperbanyak jumlah 
kekayaan serta menjaga penggunannya, yang kemudian dibahas dalam ilmu ekonomi. Serta yang berhubungan dengan tata cara (mekanisme) pendistribusiannya yang kemudian dibahas dalam sistem ekonomi.

Diantara persoalan krusial yang dilihat Taqiyuddin an-Nabhani dalam sistem ekonomi adalah konsep tentang kepemilikan sebab, semua aktivitas pengaturan harta kekayaan baik berkenaan dengan pemanfaatan, pembelajaran, pengembangan, pengalihan, atau pendistribusiannya terkait erat dengan konsep kepemilikan.

Kegiatan ekonomi merupakan hal yang tidak dapat dipisahkan dari kehidupan manusia apalagi bagi sebuah negara. Seiring perkembangan zaman ,tentu kebutuhan terhadap manusia bertambah oleh karena itu ekonomi secara terus-menerus mengalami pertumbuhan dan perubahan. Perubahan yang secara umum terjadi pada perekonomian yang dialami suatu negara seperti inflasi ,pengangguran , kesempatan kerja, hasil produksi,dan sebagainya. Jika hal ini ditangani dengan tepat maka suatu negara mengalami keadaan ekonomi yang stabil, mempengaruhi kesejahteraan kehidupan penduduk yang ada negara tersebut.

Dalam realitasnya pembangunan ekonomi yang dilaksanakan di Indonesia ternyata tidak dapat memecahkan permasalahan ekonomi. Waktu 71 tahun kemerdekaan, dari masa penjajahan, orde lama, orde baru hingga masa reformasi hingga detik ini potensi SDM, SDA, luas wilayah, dan posisi yang strategis tidak dapat digunakan untuk memecahkan problem ekonomi kita, justru permasalahan semakin kompleks dan besar. Untuk itu harus ada penggalian konsepsi ekonomi yang baru untuk menggantikan konsepsi yang sudah ada. Ekonomi Islam merupakan salah satu konsepsi ekonomi yang patut dipertimbangkan menggantikannya.

\section{PEMBAHASAN}

Paradigma riayah adalah paradigma yang menjadikan pengaturan dan pemeliharaan urusan rakyat sebagai mindset kebijakan (ri'ayatu as-su'un alummah). Maksudnya setiap pemegang kebijakan pemerintahan dia harus menjadikan kebijakannya dalam rangka pemeliharaan urusan rakyat. Dalam konsepsi Islam, maka pengaturan dan pemeliharaan urusan rakyat tersebut dilakukan menurut syariah.

Dengan paradigma ri'ayah pemerintah memikul tanggung jawab besar yakni memecahkan problem dan berposisi sebagai perisai yang melindungi rakyat. Bagaimana tanggung jawab pemerintahan dalam Islam atas rakyatnya digambarkan oleh Khalifah Umar bin Khattab berikut ini:

"Andaikan ada seekor hewan melata di wilayah Irak yang kakinya terperosok di jalan, aku takut Allah akan meminta pertanggung-jawabanku karena tidak memperbaiki jalan tersebut."

Dalam konteks kepemimpinan dan pembangunan yang telah dijalankan selama ini, kita merasakan lambatnya pemerintah melakukan pelayanan terhadap rakyatnya. Misal bila ada jalan umum yang rusak maka harus menunggu waktu yang cukup lama untuk memperbaikinya. Kebijakan ekonomi juga terkesan tidak adil sebab pertumbuhan ekonomi dijadikan acuan dalam pembangunan yang mengakibatkan kebijakan lebih berpihak kepada para investor daripada rakyat. Akibatnya pembangunan justru melahirkan kemiskinan dan ketimpangan.

Konsepsi ekonomi Islam berbeda dengan konsepsi ekonomi Kapitalis atau yang biasa disebut dengan ekonomi 
konvensional. Perbedaan itu tidak hanya mengacu pada aspek akidah atau asas, tetapi juga meliputi standar nilai, dan metode untuk mengaplikasikannya. Konsepsi ekonomi Islam mengacu pada syariah yang menjadi aturan agama kita. Sebab setiap perbuatan manusia termasuk kebijakan ekonomi dan pembangunan, serta aktivitas ekonomi masyarakat harus terikat hukum syara'._Lihat Muhammad Muhammad Ismail, Refreshing Pemikiran Islam, (al-Fikru al-Islamiy), alih bahasa A. Haidar, cet. i, (Bangil: AlIzzah, 2004), hal. 65-69.

Dalam hal bagaimana memecahkan problem ekonomi dan membangun konsepsi ekonomi menurut Islam, Taqiyuddin an-Nabhani dalam bukunya yang monumental yang berjudul an-Nizham al-Iqtishadi fii al-Islam mengemukakan pada dasarnya metode yang digunakan untuk memecahkan permasalahan ekonomi adalah sama dengan metode yang digunakan untuk memecahkan permasalahan hidup manusia lainnya._(Taqiyuddin anNabhani, Membangun Sistem Ekonomi Alternatif Perspektif Islam, (an-Nizham al-Iqtishadi fii al-Islam), alih bahasa Moh. Maghfur Wachid, cet. vii, (Surabaya: Risalah Gusti, 2002), hal. 4546), Artinya dalam seluruh bidang kehidupan manusia beserta problematikaproblematika yang dihadapinya metode pemecahannya adalah sama, yakni dengan menerapkan hukum syariah. Yang berbeda hanya bidang atau obyek yang dihukumi bukan syariahnya.

Inti permasalahan ekonomi yang harus dipecahkan adalah permasalahan perolehan kegunaan permasalahan ini berasal dari pandangan kepemilikan, pengelolaan kepemilikan, dan distribusi kekayaan- untuk memenuhi kebutuhan manusia dalam rangka mempertahankan hidup. Karena itu diperlukan suatu mekanisme yang mengatur dan mengarahkan manusia agar dapat memenuhi kebutuhan hidupnya secara layak. Dalam hal ini manusia dipandang sebagai individu yang harus dipenuhi kebutuhan hidupnya secara menyeluruh sesuai dengan kapasitasnya sebagai manusia bukan dipandang secara kolektif. Untuk memecahkan permasalahan ekonomi tersebut anNabhani menggariskan perlunya hukumhukum yang mengatur kepemilikan, pengelolaan kepemilikan, dan distribusi kekayaan (disebut juga tiga kaidah perekonomian), serta suatu politik ekonomi dalam rangka pemecahan permasalahan ekonomi. Adapun politik ekonomi Islam merupakan pemecahan masalah utama yang dihadapi setiap orang sebagai manusia yang hidup dengan interaksi-interaksi tertentu, serta memungkinkan orang tersebut untuk meningkatkan taraf hidupnya dengan gaya hidup tertentu yakni yang berlandaskan syariat Islam.

\section{Ekonomi dalam Pandangan Islam}

Menurut an-Nabhani, ekonomi merupakan kegiatan mengatur urusan harta kekayaan, baik menyangkut kegiatan untuk memperbanyak jumlah kekayaan serta menjaga pengadaannya yang dibahas dalam ilmu ekonomi, maupun kegiatan yang mengatur mekanisme distribusi kekayaan yang dibahas dalam sistem ekonomi. Berdasarkan hal ini maka pembahasan tentang ekonomi harus dipisahkan menjadi pembahasan tentang ilmu ekonomi dengan sistem ekonomi.

Ilmu ekonomi adalah ilmu yang membahas tentang produksi dan kualitasnya serta bagaimana menentukan dan memperbaiki sarana-sarananya.

Ilmu ekonomi bersifat universal karena merupakan sains murni yang tidak dipengaruhi oleh pandangan hidup tertentu. Sedangkan yang dimaksud 
dengan sistem ekonomi membahas bagaimana distribusi kekayaan dan kepemilikan, serta transaksi yang berkaitan dengan kekayaan tersebut. Sistem ekonomi bersifat khas dan dipengaruhi oleh pandangan hidup tertentu. Dalam ruang lingkup sistem ekonomi inilah Islam menetapkan adanya syariat. Dengan demikian, dalam konsepsi ekonomi Islam hanya berbicara tentang masalah bagaimana cara memperoleh kekayaan, mengelola kekayaan, dan bagaimana mendistribusikan kekayaan tersebut di tengah-tengah masyarakat. Berdasarkan hal ini hukum-hukum yang berkaitan dengan ekonomi dibangun berdasarkan pada tiga kaidah, yaitu kepemilikan, pengelolaan kepemilikan, dan distribusi kekayaan di tengah-tengah masyarakat. Selanjutnya ketiga kaidah ini disebut kaidah perekonomian.

\section{Sistem Kepemilikan}

Kepemilikan atas kekayaan hakikatnya adalah milik Allah. Allah melalui hukum-hukum-Nya telah menyerahkannya kepada manusia untuk diatur dan dibagikan. Kepemilikan dalam Islam meliputi tiga jenis, yakni kepemilikan individu, kepemilikan umum, dan kepemilikan negara. Hukum syara' atas ketiga jenis kepemilikan ini berbeda. Kepemilikan individu merupakan hukum syara' yang berlaku bagi zat ataupun kegunaan (utility) tertentu sehingga siapa saja dapat memanfaatkan dan memilikinya. Pengakuan Islam atas kepemilikan individu merupakan pengakuan atas fitrah manusia itu sendiri yakni naluri mempertahan diri. Namun Islam mengatur kepemilikan individu sehingga seseorang tidak menzalimi orang lain ataupun merusak kepentingan sosial ekonomi masyarakat. Dengan aturan ini, maka individu tidak boleh menguasai aset-aset ekonomi yang termasuk ke dalam kepemilikan negara dan kepemilikan umum.

Kepemilikan umum adalah izin Allah kepada suatu komunitas untuk bersama-sama memanfaatkan benda, yakni benda-benda yang telah dinyatakan oleh Allah untuk suatu komunitas dimana mereka masing-masing saling membutuhkan, dan Allah melarang benda tersebut dikuasai oleh individu (swasta). Benda-benda kepemilikan umum ada tiga macam, yaitu:

- Fasilitas umum yang jika tidak terdapat dalam suatu komunitas dapat menyebabkan sengketa untuk mencarinya.

- Bahan tambang yang jumlahnya tak terbatas.

- Sumber daya alam yang sifat pembentukannya menghalangi untuk dimiliki oleh individu (swasta).

Kepemilikan negara adalah harta yang menjadi hak kaum muslimin, sementara pengelolaannya menjadi wewenang khilafah, dimana khalifah dapat mengkhususkan sesuatu kepada kaum muslimin sesuai dengan apa yang menjadi pandangannya. Adapun hartaharta yang menjadi milik negara antara lain harta fai', jizyah, kharaj, dharibah.

\section{Pembentukan Struktur Ekonomi}

Problem-problem ekonomi seperti kemiskinan dan ketimpangan merupakan problem yang timbul dari kekacauan struktur ekonomi. Inti masalahnya terletak pada distribusi kekayaan sehingga untuk memecahkan harus fokus pada masalah ini.

Untuk itu bagaimana pembentukan struktur ekonomi yang menjadi domain kebijakan negara harus mengacu pada konsepsi ekonomi Islam. Sedangkan pembentukan struktur ekonomi ini 
merupakan faktor utama penentu keberhasilan pembangunan.

Struktur pertama yang harus dirombak adalah struktur sistem kepemilikan. Pembagian sistem kepemilikan menjadi kepemilikan individu, kepemilikan negara, dan kepemilikan umum merupakan langkah pembentukan struktur ekonomi yang sangat penting. Selama ini pembangunan di negeri kita menghasilkan orang-orang super kaya di satu sisi dan kemiskinan di sisi lain sehingga terjadi ketimpangan yang sangat lebar. Empat puluh orang terkaya di Indonesia sebagaimana laporan Forbes terbaru memiliki kekayaan setara $60 \%$ APBN Indonesia. Sebagian besar kekayaan mereka diperoleh dari penguasaan SDA yang dalam ekonomi Islam sebenarnya tidak boleh dikuasai individu melainkan harus dikelola negara. Inilah yang menyebabkan kemiskinan dan ketimpangan akibat struktur ekonomi yang dikuasai sekelompok kecil orang saja. Barang tambang, hutan, dan migas masuk dalam harta milik umum yang harus dikelola negara. Hasil dari pengelolaan kepemilikan umum tersebut digunakan sebagai sumber pemasukan APBN untuk membiayai pembangunan. Banyak korporat asing dan swasta yang menjadi besar dan sangat kaya karena selama ini mereka diberikan kuasa untuk mengelola pertambangan dan migas. Misalnya ExxonMobile yang bergerak dalam sektor migas memiliki pendapatan empat kali APBN Indonesia.

Struktur kedua yang harus dirombak adalah yang berkaitan dengan masalah pengembangan kekayaan atau investasi. Sistem ekonomi kapitalis menciptakan kegiatan ekonomi berbasis riba dan judi sehingga perbankan dan bursa saham menjadi poros ekonomi. Akibatnya ekonomi didominasi sektor keuangan yang mempercepat tingkat ketimpangan.
Dalam Islam semua transaksi ekonomi dan pengembangan kekayaan harus terikat hukum syara' dengan akad-akad yang syar'i dan adil. Wilayah transaksi pun hanya berada di sektor riil pada basis-basis kegiatan ekonomi yang dihalalkan syariah. Tidak ada dikotomi antara sektor riil dan sisi moneter. Sistem moneter hanya berkaitan dengan sistem mata uang emas dan perak, serta tidak ada kegiatan ekonomi yang terakit dengan riba, judi, dan spekulasi. Hal ini dinyatakan Allah dalam QS. Al-Baqarah 275.

Struktur ketiga adalah terciptanya suatu kondisi di mana setiap warga negara dapat memenuhi kebutuhan pokoknya. Politik ekonomi Islam harus menjadi basis kebijakan ekonomi. Politik ekonomi Islam adalah politik yang menjamin setiap warga negara dapat memenuhi kebutuhan pokok dan mendorong mereka untuk memenuhi kebutuhan sekunder dan tersiernya. Politik ini mencegah kebiijakan negara yang pro pertumbuhan dan pemilik modal, serta anti rakyat sebagaimana yang terjadi di Indonesia saat ini.

\section{KESIMPULAN}

Berdasarkan konsepsi ini maka peranan negara menjadi sangat penting dalam mengaplikasikan ekonomi Islam. Tanpa negara, ekonomi Islam tidak akan dapat berkontribusi untuk memecahkan masalah ekonomi dan pembentukan struktur ekonomi yang adil. Begitu pula tanpa meng-Islamkan negara tidak dapat juga Islam menjadi poros kebijakan ekonomi dan pembangunan.

Kebijakan fiskal (suatu istilah yang baru) di dalam Sistem Ekonomi Islam bukanlah merupakan suatu hal yang baru seperti halnya dalam Sistem Ekonomi Kapitalis tetapi ia sudah 
dipraktekkan sejak negara Islam pertama kali berdiri.

Kebijakan fiskal adalah kebijakan yang berkaitan dengan pendapatan dan pengeluaran Negara yang diatur oleh pemerintah. Rasulullah berpedoman dengan Al-Qur'an terhadap penentuan kebijakan fiskal, seperti Q.S. Al-Anfal ayat 41 tentang ghanimah, Q.S. Al-Hasyr ayat 6 tentang fay' $i$, Q.S. At-Taubah ayat 29 tentang jizyah dan Q.S. At-Taubah ayat 60 tentang zakat.

Kebijakan fiskal dari sisi penerimaan negara didasarkan atas sumber-sumber penerimaan negara yaitu dari Bagian Fai dan Kharaj, Bagian Pemilikan Umum, dan Bagian Shadaqah. Jika sumber-sumber penerimaan negara tidak mencukupi belanja negara terutama yang sifatnya wajib, maka negara diperbolehkan menarik pajak dari kaum Muslimin untuk menutupi kekurangan anggaran negara.

Kebijakan fiskal dari sisi pengeluaran negara dilandasi oleh suatu politik ekonomi Islam, yaitu menjamin pemenuhan kebutuhan-kebutuhan primer (al-hajat al-asasiyah/ basic needs) perindividu secara menyeluruh, dan membantu tiap-tiap individu di antara mereka dalam memenuhi kebutuhankebutuhan sekunder dan tersiernya (alhajat al-kamaliyah) sesuai kadar kemampuannya. Atas dasar politik ekonomi inilah negara melakukan kebijakan fiskal dari sisi pengeluaran untuk menciptakan suatu mekanisme distribusi ekonomi yang adil.

\section{DAFTAR PUSTAKA}

Adiwarman A. Karim, Bank Islam: Analisis Fiqh dan Keuangan, Jakarta : PT. Rajagrafindo Persada, 2004

Al-Mushlih, Abdullah \& Ash-Shawi, Shalah, Fikih Ekonomi Keuangan Islam (Mâ Lâ Yasa'u at-Tâjir
Jahlah), Penerjemah Abu Umar Basyir. Jakarta Darul Haq, 2004

Heri Sudarsono, Konsep Ekonomi Islam Suatu Pengantar, Yogyakarta: Ekonisia, 2004

Heri Sudarsono, Bank dan Lembaga keuangan Syariah, Yogyakarta: Ekonisisa, 2004.

Munrokhim Misanan, dkk, Ekonomi Islam, Kerjasama LP3EI dan BI, Jakarta: Raja Grafindo Persada, 2008

Syahid Muhammad Baqir al- Shadr, Keunggulan Ekonomi Islam, Mengkaji Sistem Ekonomi Barat dengan Kerangka Pemikiran Sistem Ekonomi Islam , Jakarta: Pustaka Zahra, 2002

Taqiyuddin an Nabhani, Membangun Sistem Ekonomi Alternatif Prespektif Isam (terj.), Surabaya: Risalah Gusti, 1996.

Yusuf Qardhawi, Norma dan Etika Ekonomi Islam, Jakarta: Gema Insani Press, 1997 